\title{
Energy-dependent Electrospray Ionisation Mass Spectrometry of Carbonyl Clusters*
}

\author{
Evan Crawford, ${ }^{1}$ Paul J. Dyson, ${ }^{2}$ Orissa Forest, ${ }^{1}$ Samantha Kwok, ${ }^{1}$ \\ and $\mathbf{J}$. Scott McIndoe ${ }^{1,3}$
}

Received December 1, 2005; published online January 19, 2006

\begin{abstract}
The electrospray ionisation mass spectra (EDESI-MS) of $\mathrm{Ru}_{6} \mathrm{C}(\mathrm{CO})_{16}\left(\mathrm{PPh}_{3}\right)$ and $\mathrm{Ir}_{4}(\mathrm{CO})_{11}\left(\mathrm{PR}_{3}\right)\left(\mathrm{PR}_{3}=\mathrm{PPh}_{3}, \mathrm{P}\left(p-\mathrm{C}_{6} \mathrm{H}_{4} \mathrm{OMe}\right)_{3}, \mathrm{P}\left(p-\mathrm{C}_{6} \mathrm{H}_{4} \mathrm{NMe}_{2}\right)_{3}, \mathrm{P}\left(p-\mathrm{C}_{6} \mathrm{H}_{4} \mathrm{Cl}\right)_{3}\right.$, $\left.\mathrm{P}(\mathrm{OPh})_{3}, \mathrm{P}(\mathrm{OMe})_{3}, \mathrm{PO}_{3} \mathrm{C}_{5} \mathrm{H}_{9}\right)$ are described and the relative importance of carbonyl loss versus phosphine loss as a fragmentation pathway is assessed. Qualitatively, the phosphine ligands bind more strongly to $\operatorname{Ir}_{4}(\mathrm{CO})_{11}$ clusters than to $\mathrm{Ru}_{6} \mathrm{C}(\mathrm{CO})_{16}$. The influence on the collision cell pressure on MS/MS spectra of transition metal carbonyl cluster anions is also explored showing that a greater, simultaneous, distribution of fragment ions is produced as the collision cell pressure is increased.
\end{abstract}

KEY WORDS: carbonyl clusters; mass spectrometry; electrospray ionisation.

\section{INTRODUCTION}

While X-ray crystallography was pivotal in the development of cluster science, mass spectrometry has also played an important role, not only where X-ray data could not be obtained, but to help elucidate the nature of clusters present in mixtures where the crystal used for the structure determination was not representative of the bulk material. Traditional ionisation techniques are quite effective for volatile clusters that are reasonably thermally stable, and have been used for some time. For

\footnotetext{
*Dedicated to Prof. Brian F. G. Johnson on the occasion of his retirement.

${ }^{1}$ Department of Chemistry, University of Victoria, P.O. Box 3065, Victoria, BC V8W 3V6, Canada.

${ }^{2}$ Institut des Sciences et Ingénierie Chimiques, Ecole Polytechnique Fédérale de Lausanne (EPFL), CH-1015, Lausanne, Switzerland.

${ }^{3}$ To whom correspondence should be addressed. E-mail: mcindoe@uvic.ca
} 
example, excellent spectra of osmium clusters as large as $\mathrm{Os}_{8} \mathrm{C}(\mathrm{CO})_{21}$ were obtained using electron impact mass spectrometry some 25 years ago [1]. These spectra correctly identified the number of carbonyl ligands. For these large clusters elemental analysis and spectroscopic methods provided very little useful information, so the ability of mass spectrometry to establish the molecular formula was crucial. Furthermore, mass spectrometry allowed the successful identification of interstitial carbide atoms in the hexarutheniumcarbide clusters $\mathrm{Ru}_{6} \mathrm{C}(\mathrm{CO})_{17}$ and $\mathrm{Ru}_{6} \mathrm{C}(\mathrm{CO})_{14}$ (arene) [2] prior to their characterisation in the solid state [3]. Despite the development of cluster chemistry in the 1960s, study of polynuclear carbonyl clusters by mass spectrometry was not a routine technique. Instrument operators were often suspicious that decomposition of clusters in the machine would lead to their machines being damaged or ruined by metal deposits. However, these fears proved largely unfounded and early experiments on simple binary carbonyl clusters [4, 5] were soon followed by studies of larger clusters [6]. Despite difficulties with carbonyl hydride clusters due to complications arising from the loss of both $\mathrm{H}$ and $\mathrm{CO}$ groups [7], mass spectrometry was shown to be a useful tool for elucidating the correct stoichiometry of such compounds [8]. One advantage in the study of neutral metal carbonyl clusters is their reasonably high volatility. The high vacuum and elevated temperatures used in conventional mass spectrometry did not preclude the study of the more robust species.

However, substituted, thermally sensitive and charged clusters, with or without carbonyl ligands, remained inaccessible to mass spectrometry due to lack of volatility or decomposition. Development of the ionisation techniques of fast atom bombardment [9] and ${ }^{252} \mathrm{Cf}$ plasma desorption [10] helped the situation somewhat, but it has been the comparatively recent development of matrix-assisted laser desorption ionisation (MALDI) [11] and electrospray ionisation (ESI) [12] that has made the determination of molecular weights of high nuclearity clusters routine [13]. ESI in particular, has been applied to cluster molecules [14], since this technique provides a straightforward and superior determination of molecular weights for these compounds, in contrast to LDI, which tends to give much more complicated spectra [15]. ESI-MS is particularly powerful in that it copes with mixtures with ease and retains charge information; for example, the structurally characterised cluster $\left[\mathrm{Os}_{20}(\mathrm{CO})_{40}\right]^{2-}[16]$ was shown, recently, to comprise a mixture of high nuclearity species including $\left[\mathrm{Os}_{20}(\mathrm{CO})_{40}\right]^{3-}$ and $\left[\mathrm{Os}_{19}(\mathrm{CO})_{39}\right]^{2-}[17]$.

ESI and MALDI are both soft ionisation techniques; that is, under standard conditions they provide spectra that are essentially free from fragmentation. While this property is crucial to their success in obtaining reliable molecular weight information, it reduces the structural information 
inherent in other forms of mass spectra. This weakness was immediately identified and instruments were fitted with the capability of breaking apart parent ions using collision-induced dissociation, either in the collision cell of an MS/MS instrument or in the in-source region, immediately prior to the ions being introduced to the mass spectrometer. Application of additional energy to the ions in these regions increases the impact of the collisions with (essentially) stationary gas molecules, and breaks the ions apart in a structurally informative way. The extent of fragmentation can be finely tuned, and so the process of fully interrogating a compound across the full range of collision energies generates an enormous amount of data. Interpreting this data in a meaningful way calls for an alternative approach to simply stacking individual spectra, and energy dependent ESI-MS (EDESI-MS) achieves this through complete (as opposed to a random selection) collection of all data and presentation in a map format, whereby a new dimension of data (the energy at which a given ion appears) is added to the data [18]. In this paper EDESI-MS is applied to carbonyl clusters with phosphine ligands and the influence of collision gas pressure on the spectra is demonstrated.

\section{EXPERIMENTAL}

The clusters $\mathrm{Ru}_{6} \mathrm{C}(\mathrm{CO})_{16}\left(\mathrm{PPh}_{3}\right)$ [19], $\mathrm{Ir}_{4}(\mathrm{CO})_{11}\left(\mathrm{PR}_{3}\right) \quad\left(\mathrm{PR}_{3}=\mathrm{PPh}_{3}\right.$, $\mathrm{P}\left(p-\mathrm{C}_{6} \mathrm{H}_{4} \mathrm{OMe}\right)_{3}, \quad \mathrm{P}\left(p-\mathrm{C}_{6} \mathrm{H}_{4} \mathrm{NMe}_{2}\right)_{3}, \quad \mathrm{P}\left(p-\mathrm{C}_{6} \mathrm{H}_{4} \mathrm{Cl}\right)_{3}, \quad \mathrm{P}(\mathrm{OPh})_{3}, \quad \mathrm{P}(\mathrm{OMe})_{3}$, $\mathrm{PO}_{3} \mathrm{C}_{5} \mathrm{H}_{9}$ [20], [ $\left.\mathrm{NEt}_{4}\right]_{2}\left[\mathrm{Fe}_{6} \mathrm{C}(\mathrm{CO})_{16}\right]$ [21], [PPN][CoRu$\left.{ }_{3}(\mathrm{CO})_{13}\right]$ [22] and $[\mathrm{PPN}]_{2}\left[\mathrm{Ru}_{6} \mathrm{C}(\mathrm{CO})_{16}\right][23]$ were prepared according to literature procedures. Neutral clusters were prepared for mass spectrometric analysis by a previously published method to generate $[\mathrm{M}+\mathrm{OMe}]^{-}$ions. EDESI-MS/ MS data were collected on a Micromass QTof micro using the following settings. The capillary voltage was set at $2900 \mathrm{~V}$ and the source and desolvation gas (nitrogen) temperatures to $100^{\circ} \mathrm{C}$. Samples were introduced directly to the source at $5 \mu \mathrm{L} \mathrm{min}^{-1}$ as a dichloromethane solution, ca. $0.01 \mathrm{mmol} \mathrm{L}^{-1}$ via a syringe pump. Data collection was carried out in continuum mode. Cone voltage was set at $20 \mathrm{~V}$ to maximise the intensity of the parent ion, which was selected using MS1. The collision voltage was ramped from 0 to $100 \mathrm{~V}$ to generate the continuum data. Scan time was $1 \mathrm{~s}$ per spectrum, so a complete spectrum took less than 2 min to collect. Remaining mass spectra were collected on a Micromass Quattro LC using the following settings. The capillary voltage was set at $2900 \mathrm{~V}$ and the source and desolvation gas (nitrogen) temperatures to $100^{\circ} \mathrm{C}$. Samples were introduced directly to the source at $8 \mu \mathrm{L} \mathrm{min}{ }^{-1}$ via a syringe pump. Data collection was carried out in continuum mode. Cone voltage was set at $20 \mathrm{~V}$ to maximise the intensity of the parent ion, which was selected using MS1. 
The voltage across the collision cell was set to ensure the intact cluster was present at lowest gas pressures and the bare metal core was produced at the highest gas pressure (50 V for both clusters). A scan time of $8 \mathrm{~s}$ per spectrum and a low resolution setting (peak width at half-height $\sim 0.8 \mathrm{Da}$ ) was used to maximise the signal-to-noise ratio. A full scan took approximately 9 min to

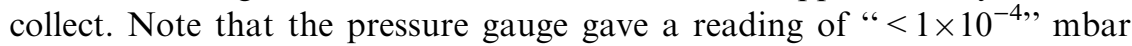
for all pressure readings below this threshold. However, there were certainly changes in the spectra below this point, hence the scale on the PDESI spectra descends below 0.0001 mbar.

\section{RESULTS AND DISCUSSION}

\section{Fragmentation of Phosphine-substituted Metal Carbonyl Clusters}

EDESI-MS maps for homoleptic carbonyl cluster anions reveal sequential loss of carbonyl ligands until, at high cone voltage, the naked metal core is observed. The loss of CO ligands is clear from the conventional (summed) 1D spectrum shown at the top of the figure, and is also apparent from the peaks in the 2D map, each showing the collision energies over which the loss of the ligand occurs (see below). Spectra have been reported previously for $\left[\mathrm{Ru}_{5} \mathrm{CoC}(\mathrm{CO})_{16}\right]^{-}$[24] and various other metal carbonyl anions [18]. In the EDESI-MS of these types of compounds the pattern of intensities is generally straightforward to interpret. The analysis of mixtures of clusters, for example, was demonstrated for a series of heteronuclear ruthenium-cobalt clusters prior to their chromatographic separation [25]. Essentially, each cluster present produced a distinct series of peaks and the smaller clusters are instantly recognised, rather than mistaken as fragments of the higher molecular weight species. In particular, the appearance of each discrete species at the lowest cone voltages indicates the presence of a mixture.

Clusters with ligands other than carbonyls (and $-\mathrm{C}(\mathrm{O}) \mathrm{OMe}$, the ligand derived from addition of methoxide ion to neutral metal carbonyl clusters to obtain a charged species) [26] have not been studied in detail. In the case of $\left[\mathrm{Ru}_{6} \mathrm{C}(\mathrm{CO})_{16}\left(\mathrm{PPh}_{3}\right)+\mathrm{OMe}\right]^{-}$, the phosphine ligand is lost first in the fragmentation process (Fig. 1) and the pattern is otherwise entirely reminiscent of that of the parent cluster, $\left[\mathrm{Ru}_{6} \mathrm{C}(\mathrm{CO})_{17}+\mathrm{OMe}\right]^{-}$[27].

Competing fragmentation processes can occur for closely related clusters such that the EDESI spectrum requires careful interpretation. Investigating the series of clusters $\operatorname{Ir}_{4}(\mathrm{CO})_{11}\left(\mathrm{PR}_{3}\right) \quad\left(\mathrm{PR}_{3}=\mathrm{PPh}_{3}, \mathrm{P}\left(p-\mathrm{C}_{6} \mathrm{H}_{4} \mathrm{OMe}\right)_{3}\right.$, $\left.\mathrm{P}\left(p-\mathrm{C}_{6} \mathrm{H}_{4} \mathrm{NMe}_{2}\right)_{3}, \mathrm{P}\left(p-\mathrm{C}_{6} \mathrm{H}_{4} \mathrm{Cl}\right)_{3}, \mathrm{P}(\mathrm{OPh})_{3}, \mathrm{P}(\mathrm{OMe})_{3}, \mathrm{PO}_{3} \mathrm{C}_{5} \mathrm{H}_{9}\right)$ reveals that loss of CO competes with phosphine loss (see Table I for $m / z$ values of the clusters analysed in this paper). 


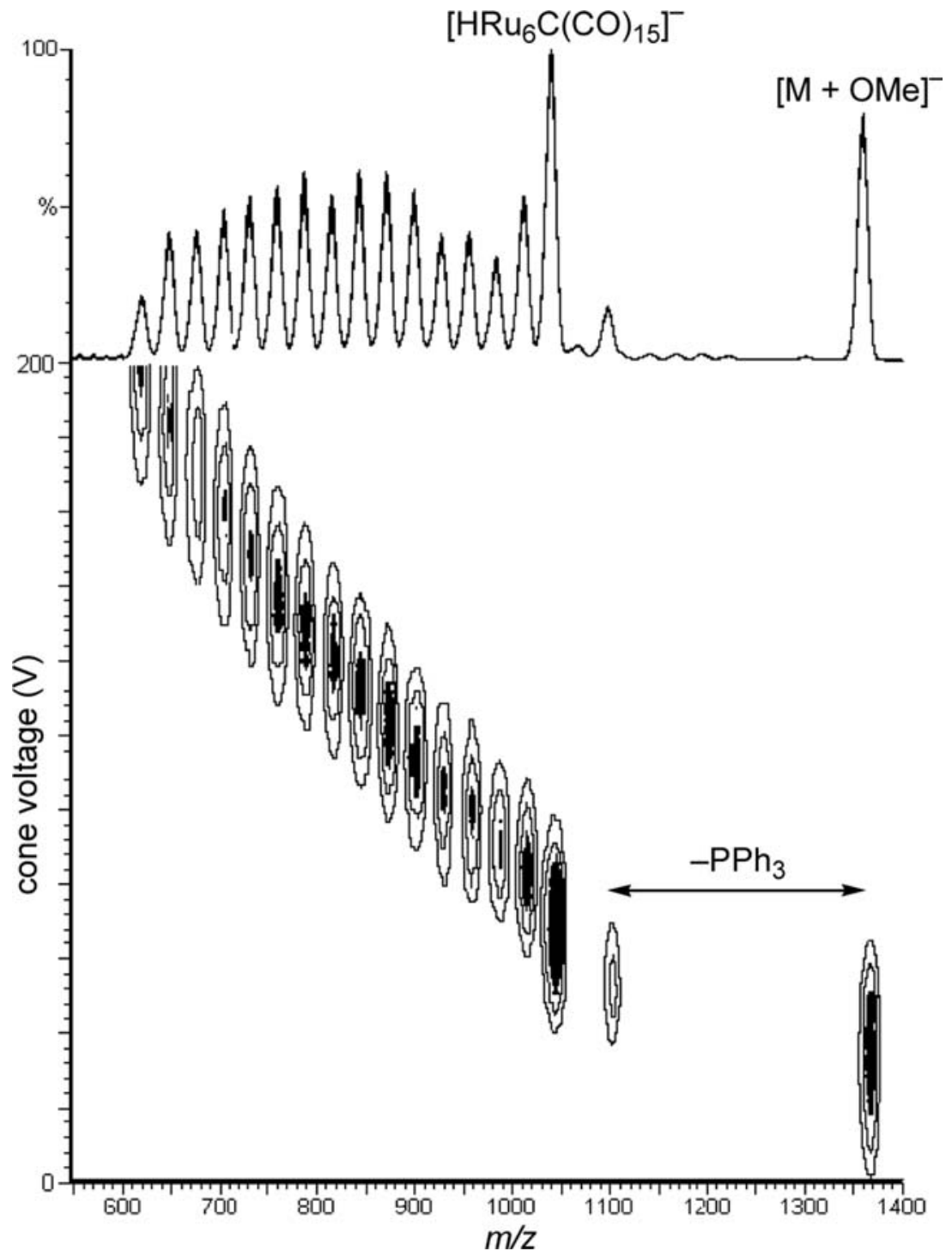

Fig. 1. Negative-ion EDESI-MS of $\left[\mathrm{Ru}_{6} \mathrm{C}(\mathrm{CO})_{16}\left(\mathrm{PPh}_{3}\right)+\mathrm{OMe}\right]^{-}$.

Typical EDESI spectra are shown in Fig. 2 for $\operatorname{Ir}_{4}(\mathrm{CO})_{11}\left(\mathrm{PPh}_{3}\right)$ and Fig. 3 for $\operatorname{Ir}_{4}(\mathrm{CO})_{11}\left\{\mathrm{P}\left(p-\mathrm{C}_{6} \mathrm{H}_{4} \mathrm{Cl}\right)_{3}\right\}$. Considering the EDESI mass spectrum of $\operatorname{Ir}_{4}(\mathrm{CO})_{11}\left(\mathrm{PPh}_{3}\right)$, similar to the spectra observed for the analysis of mixtures of clusters, two sets of peaks are observed. However, one set 
Table I. $m / z$ Values of the Intact Clusters

$m / z$ (of the most intense peak in the isotope pattern)

\begin{tabular}{lc}
\hline$\left[\mathrm{Ru}_{6} \mathrm{C}(\mathrm{CO})_{16}\left(\mathrm{PPh}_{3}\right)+\mathrm{OMe}\right]^{-}$ & 1361 \\
{$\left[\mathrm{Ir}_{4}(\mathrm{CO})_{11}\left(\mathrm{PPh}_{3}\right)+\mathrm{OMe}\right]^{-}$} & 1371 \\
{$\left[\mathrm{Ir}_{4}(\mathrm{CO})_{11}\left\{\mathrm{P}\left(p-\mathrm{C}_{6} \mathrm{H}_{4} \mathrm{OMe}\right)_{3}\right\}+\mathrm{OMe}^{-}\right.$} & 1461 \\
{$\left[\mathrm{Ir}_{4}(\mathrm{CO})_{11}\left\{\mathrm{P}\left(p-\mathrm{C}_{6} \mathrm{H}_{4} \mathrm{NMe}_{2}\right)_{3}\right\}+\mathrm{OMe}\right]^{-}$} & 1500 \\
{$\left[\mathrm{Ir}_{4}(\mathrm{CO})_{11}\left\{\mathrm{P}\left(p-\mathrm{C}_{6} \mathrm{H}_{4} \mathrm{Cl}\right)_{3}\right\}+\mathrm{OMe}\right]^{-}$} & 1473 \\
{$\left[\mathrm{Ir}_{4}(\mathrm{CO})_{11}\left\{\mathrm{P}(\mathrm{OPh})_{3}\right\}+\mathrm{OMe}\right]^{-}$} & 1419 \\
{$\left[\mathrm{Ir}_{4}(\mathrm{CO})_{11}\left(\mathrm{PO}_{3} \mathrm{C}_{5} \mathrm{H}_{9}\right)+\mathrm{OMe}\right]^{-}$} & 1257 \\
{$\left[\mathrm{Fe}_{6} \mathrm{C}(\mathrm{CO})_{16}\right]^{--}$} & 398 \\
{$\left[\mathrm{CoRu}_{3}(\mathrm{CO})_{13}\right]^{-}$} & 728 \\
{$\left[\mathrm{Ru}_{6} \mathrm{C}(\mathrm{CO})_{16}\right]^{2-}$} & 535 \\
\hline
\end{tabular}

commences at a threshold cone voltage $(1371 \mathrm{~m} / \mathrm{z})$ while the other commences at a cone voltage of $\sim 29 \mathrm{~V}(1051 \mathrm{~m} / \mathrm{z})$. This latter series of peaks is indicative of an alternative fragmentation pathway and does not correspond to the presence of a second compound in the sample. Two competing fragmentation pathways were observed previously for the cluster $\left[\mathrm{Pt}_{3} \mathrm{Ru}_{10} \mathrm{C}_{2}(\mathrm{CO})_{32}\right]^{2-}$, which either loses all $\mathrm{CO}$ ligands down to the $\mathrm{Pt}_{3} \mathrm{Ru}_{10} \mathrm{C}_{2}$ core or the cluster splits in two to form $\left[\mathrm{PtRu}_{5} \mathrm{C}(\mathrm{CO})_{15}\right]^{-}$and $\left[\mathrm{Pt}_{2} \mathrm{Ru}_{5} \mathrm{C}(\mathrm{CO})_{16}\right]^{-}[28]$.

In fact, the peak at $1051 \mathrm{~m} / \mathrm{z}$ is readily assigned to that of the cluster in which both one $\mathrm{CO}$ ligand and the $\mathrm{PPh}_{3}$ ligand have been lost, and subsequently the sequential loss of the remainder of the $\mathrm{CO}$ ligands is observed, down to the $\left[\mathrm{HIr}_{4}\right]^{-}$core. A slight complication in the spectrum is the loss of formaldehyde, generated from the methoxycarbonyl ligand (itself derived from the derivatisation of the cluster by methoxide to give an $[\mathrm{M}+\mathrm{OMe}]^{-}$ion) [26]. This phenomenon has been discussed previously [27], and will not be dealt with in any detail here beyond stating that this process occurs relatively early in the fragmentation process. It makes little difference to the gross appearance of the EDESI map, as the mass loss due to formaldehyde $(30 \mathrm{~m} / z)$ is close to that of CO itself $(28 \mathrm{~m} / \mathrm{z})$. For the ions which retain the $\mathrm{PPh}_{3}$ ligand, at $48 \mathrm{~V}$ loss of phenyl begins to compete with $\mathrm{CO}$ loss, generating another series of fragment peaks. At $64 \mathrm{~V}$, another series due to loss of two phenyl groups from the $\mathrm{PPh}_{3}$ ligand appears, and these two series dominate above $95 \mathrm{~V}$, beyond which point no ions remain that contain the intact $\mathrm{PPh}_{3}$ ligand. At the highest cone voltages the $\left[\mathrm{HIr}_{4} \mathrm{PPh}_{2}\right]^{-}$and $\left[\mathrm{HIr}_{4} \mathrm{PPh}\right]^{-}$ions appear to undergo dehydrogenation (loss of $\mathrm{H}_{2}$ ) until at $200 \mathrm{~V}$, the ions present correspond to $\left[\mathrm{Ir}_{4} \mathrm{PC}_{6}\right]^{-}$and $\left[\mathrm{Ir}_{4} \mathrm{PC}_{12} \mathrm{H}_{4}\right]^{-}$, respectively. 


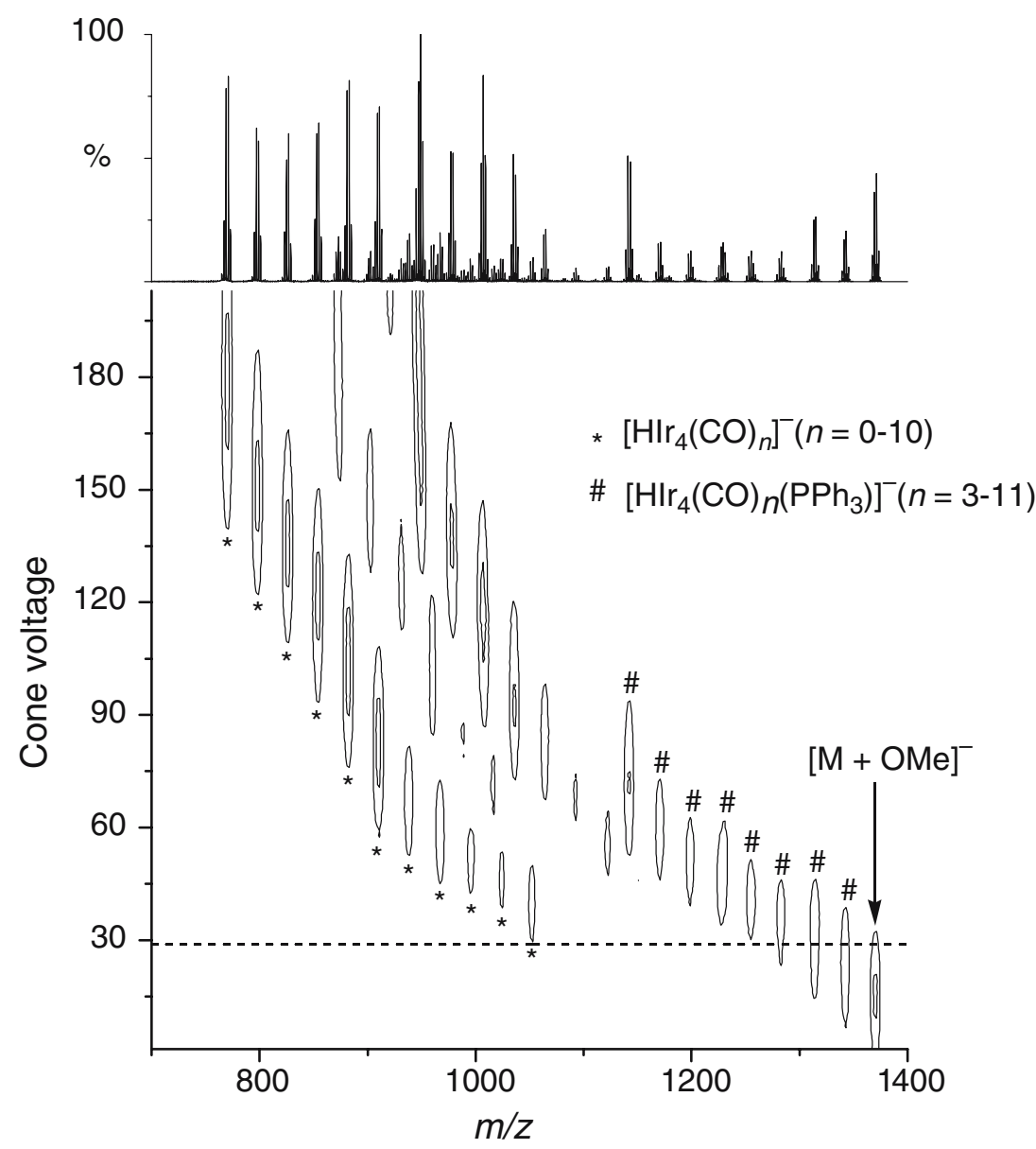

Fig. 2. Negative-ion EDESI mass spectrum of $\left[\mathrm{Ir}_{4}(\mathrm{CO})_{11}\left(\mathrm{PPh}_{3}\right)+\mathrm{OMe}\right]^{-}$. Peaks not marked with "*" or "\#" correspond to ions resulting from fragmentation of the $\mathrm{PPh}_{3}$ ligand.

Vacant coordination sites next to a triphenylphosphine ligand can easily lead to metallation of the ortho-C-H bond of the phenyl group [29], and it seems likely that this process occurs during the fragmentation of the cluster. Migration of $\mathrm{H}$ to the cluster probably facilitates loss of the other phenyl groups from the ligand, as these may be eliminated with $\mathrm{H}$ as benzene rather than as the higher energy phenyl radical or benzyne.

Similar patterns are observed for the EDESI-MS of $\left[\operatorname{Ir}_{4}(\mathrm{CO})_{11}\{\mathrm{P}(p-\right.$ $\left.\left.\left.\mathrm{C}_{6} \mathrm{H}_{4} \mathrm{Cl}\right)_{3}\right\}+\mathrm{OMe}\right]^{-}$(Fig. 3) and $\left[\mathrm{Ir}_{4}(\mathrm{CO})_{11}\left\{\mathrm{P}\left(p-\mathrm{C}_{6} \mathrm{H}_{4} \mathrm{NMe}_{2}\right)_{3}\right\}+\mathrm{OMe}\right]^{-}$ (Fig. 4). The EDESI-MS of $\left[\operatorname{Ir}_{4}(\mathrm{CO})_{11}\left\{\mathrm{P}(\mathrm{OPh})_{3}\right\}+\mathrm{OMe}^{-}\right.$(Fig. 5) appears 
somewhat different, with the intact ligand surviving on the cluster until very high cone voltages are reached. This effect is most likely due to the ability of the -OPh groups to compensate for $\mathrm{CO}$ loss by donating oxygen lone pairs, making the ligand more resistant to fragmentation due to this formation of additional metal-ligand bonding.

It is worth noting that a complicated series of peaks is not only attributable to mixtures of compounds or competitive fragmentation pathways, but that polyhedral rearrangements of an open cluster core can

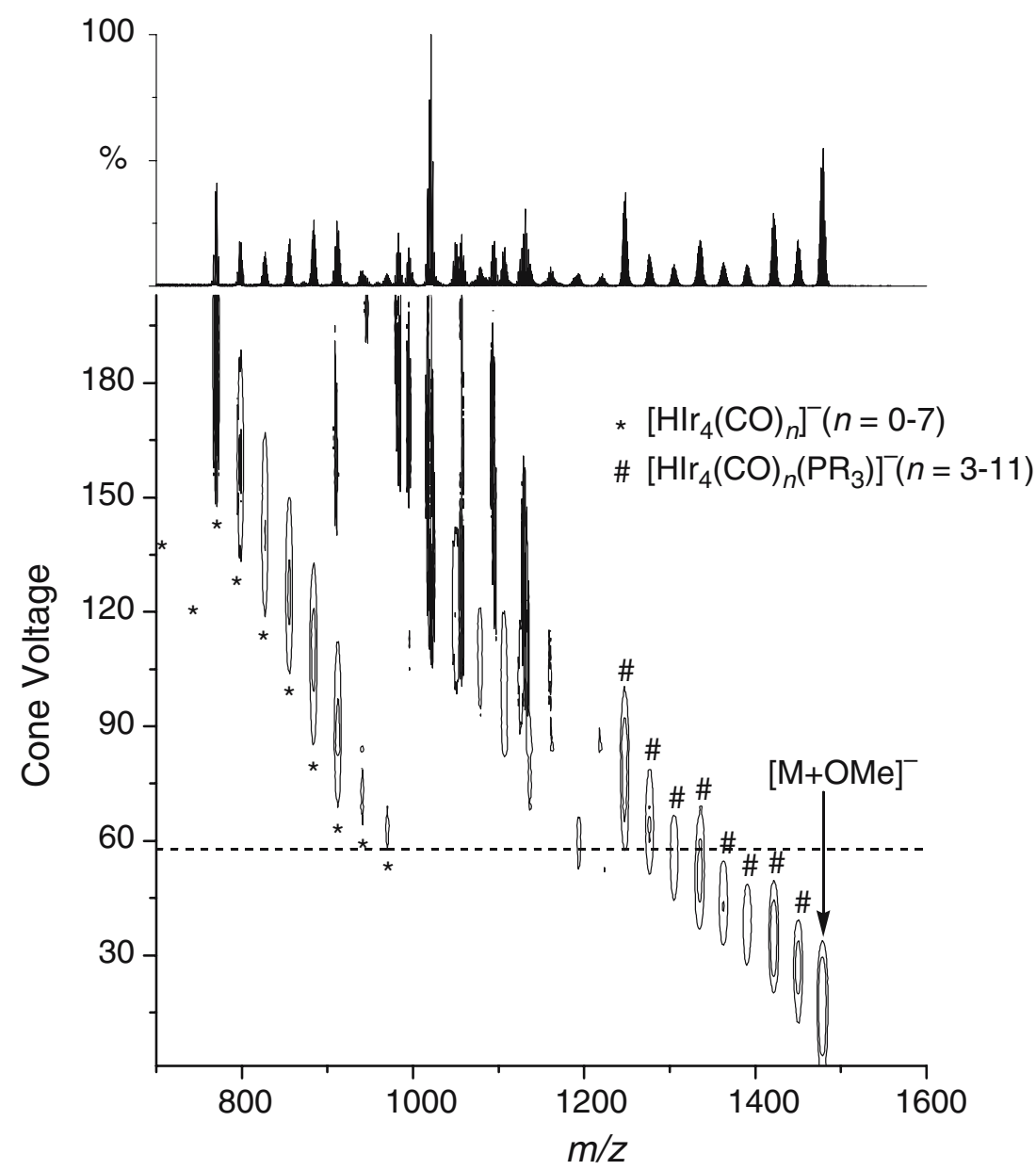

Fig. 3. Negative-ion EDESI mass spectrum of $\left[\mathrm{Ir}_{4}(\mathrm{CO})_{11}\left\{\mathrm{P}\left(p-\mathrm{C}_{6} \mathrm{H}_{4} \mathrm{Cl}\right)_{3}\right\}+\mathrm{OMe}\right]^{-}$. Peaks not marked with "*" or "\#" correspond to ions resulting from fragmentation of the $\mathrm{P}(p$ $\left.\mathrm{C}_{6} \mathrm{H}_{4} \mathrm{Cl}\right)_{3}$ ligand. 


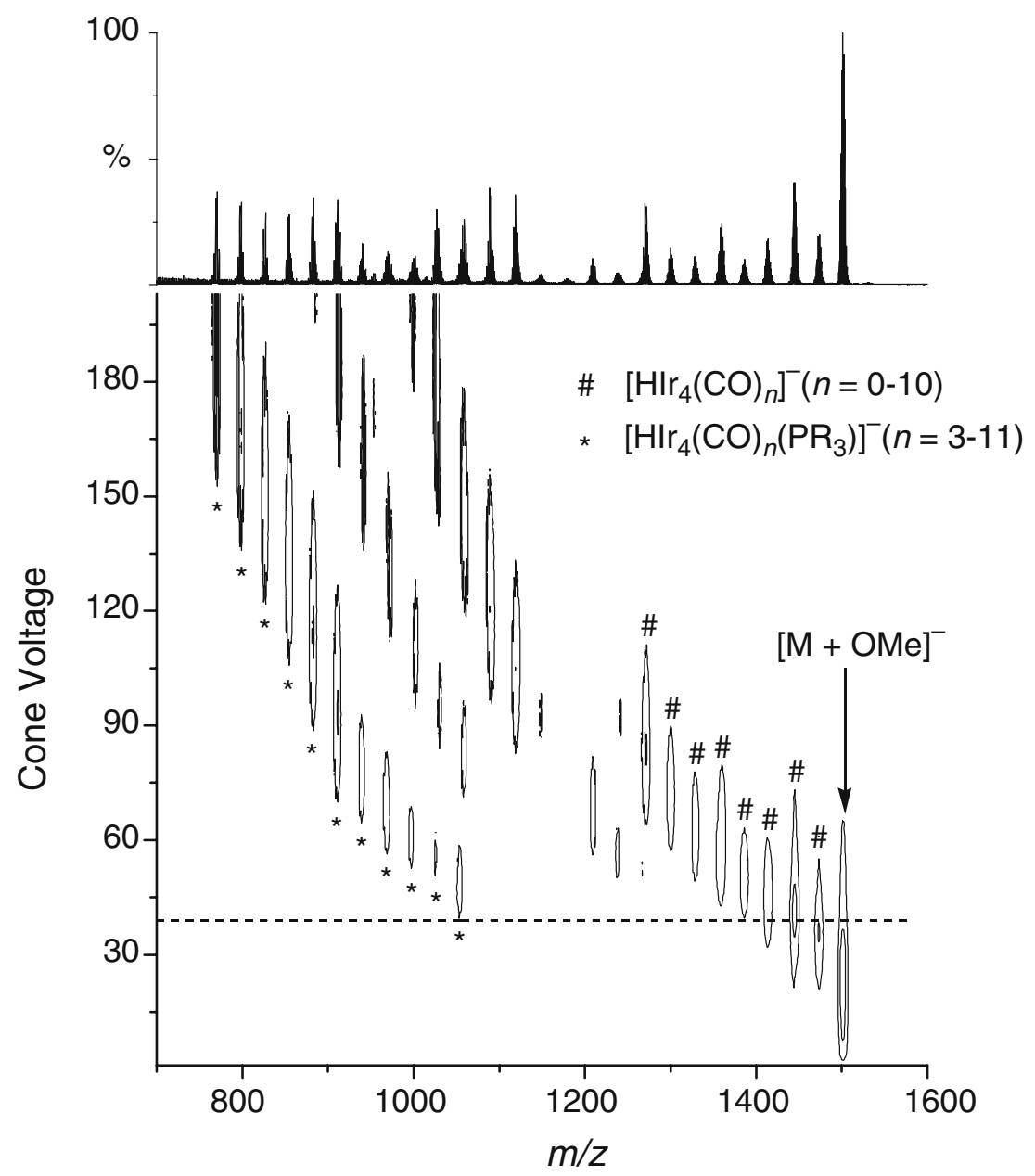

Fig. 4. Negative-ion EDESI mass spectrum of $\left[\mathrm{Ir}_{4}(\mathrm{CO})_{11}\left\{\mathrm{P}\left(p-\mathrm{C}_{6} \mathrm{H}_{4} \mathrm{NMe}_{2}\right)_{3}\right\}+\mathrm{OMe}\right]^{-}$. Peaks not marked with "**" or "\#" correspond to ions resulting from fragmentation of the $\mathrm{P}(p$ $\left.\mathrm{C}_{6} \mathrm{H}_{4} \mathrm{NMe}_{2}\right)_{3}$ ligand.

also result in markedly irregular peak intensities [28]. Accordingly, all but the simplest EDESI mass spectra must always be interpreted with caution, nonetheless, the additional information obtained by this technique can be highly informative. If the series of tetrairidium carbonyl clusters with a monophosphine ligand are considered further then it is clear that the Ir-P bond strength is greater than that of the $\mathrm{Ir}-\mathrm{CO}$ bond, whereas for 


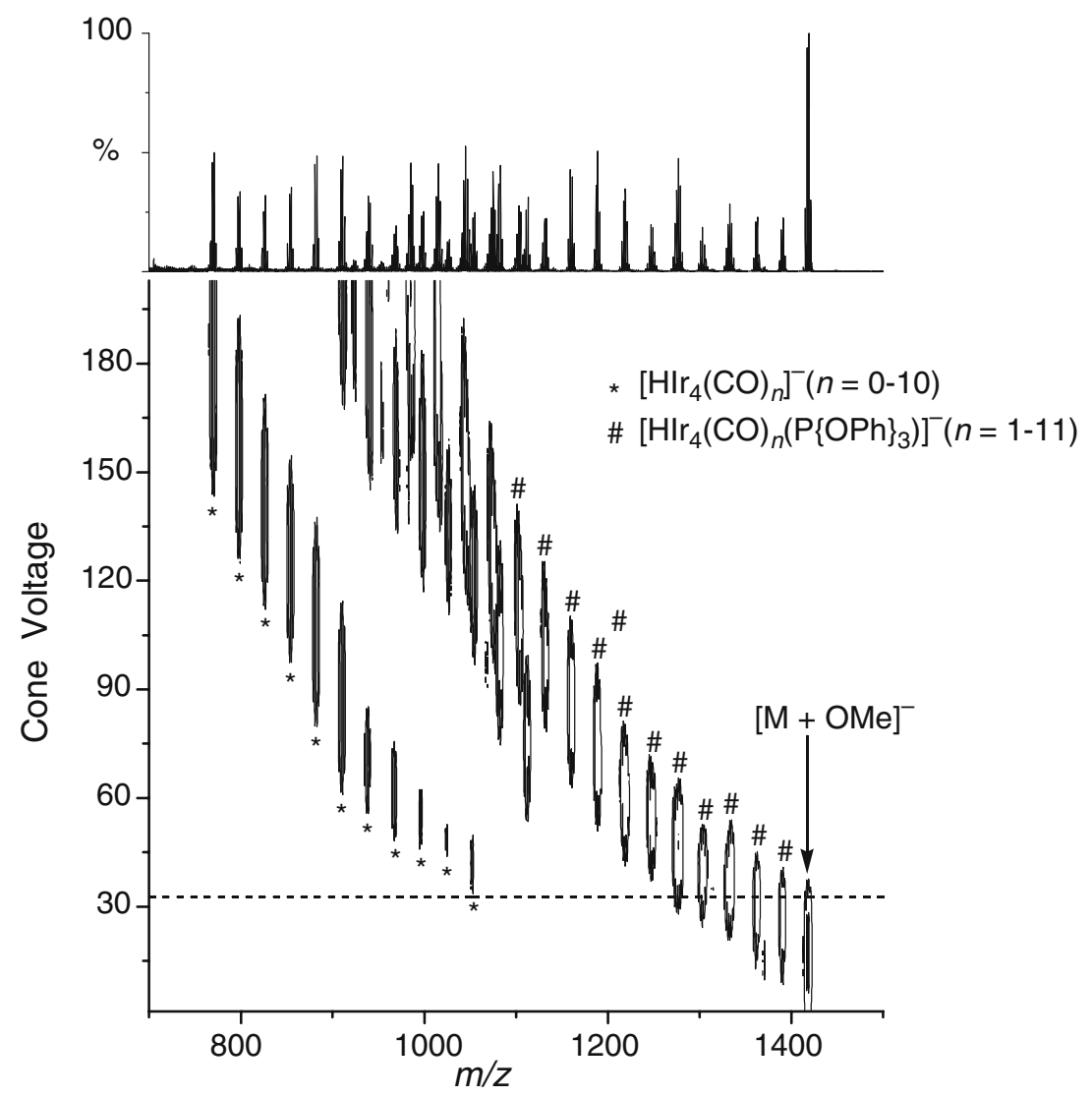

Fig. 5. Negative-ion EDESI mass spectrum of $\left[\operatorname{Ir}_{4}(\mathrm{CO})_{11}\left\{\mathrm{P}(\mathrm{OPh})_{3}\right\}+\mathrm{OMe}\right]^{-}$. Peaks not marked with "**" or "\#" correspond to ions resulting from fragmentation of the $\mathrm{P}(\mathrm{OPh})_{3}$ ligand.

$\left[\mathrm{Ru}_{6} \mathrm{C}(\mathrm{CO})_{17}+\mathrm{OMe}\right]-$ the situation is reversed. This feature is in agreement with the fact that $\operatorname{Ir}_{4}(\mathrm{CO})_{12}$ is markedly easier to multiply substitute with phosphine ligands compared to $\mathrm{Ru}_{6} \mathrm{C}(\mathrm{CO})_{17}$ [30].

Note that extraction of ligand binding energies from threshold collision-induced dissociation studies of ions using a tandem mass spectrometer is possible, but only under rigorously controlled single collision conditions [31]. In our studies, multiple collisions are accumulated to fragment the ions, so no quantitative analysis of ligand binding energies has been attempted. 


\section{The Effect of Collision Gas Pressure in the MS/MS Studies of Transition Metal Carbonyl Clusters}

Energy-dependent mass spectrometry depends on collision-induced dissociation [32] to fragment ions. Other parameters capable of fragmenting ions can also be varied to generate related maps. In particular, altering the temperature of the heated capillary leading from the spray chamber to the ion optics in an ion trap instrument results in a "temperature-dependent" spectrum [33]; similarly, the laser power in laser desorption ionisation experiments may be modulated to provide differing degrees of fragmentation versus aggregation [34]. Observation of these effects led us to reinvestigate our EDESI-MS/MS studies, as no mention of the influence of the collision gas pressure on the spectrum had been previously made. It is well established that the collision gas pressure has a large effect on the extent of fragmentation at a given energy [35], and this may be demonstrated by collection of fragmentation data at a set collision energy, and varying only the gas pressure. Figure 6 shows negative-ion EDESI-MS/MS spectra of $\left[\mathrm{Fe}_{6} \mathrm{C}(\mathrm{CO})_{16}\right]^{2-}$ collected at collision gas pressures of 1.39 and $2.66 \times 10^{-5}$ mbar.

The collision gas pressure exerts a significant effect on the fragmentation process. At low pressure, only a few carbonyl ligands are eliminated from the cluster core, even at high values of the collision energy. In contrast, by increasing the pressure the elimination of all 16 carbonyl ligands from the octahedral metal cluster core takes place. Increasing the pressure still further had only a small effect on the EDESI map, slightly decreasing the collision voltages required to reach a given fragmentation. Note that midway through the fragmentation process the cluster undergoes an electron autodetachment event. Loss of an electron from multiply charged anions in the gas phase is a well-known phenomenon [36], and is due to the increase in Coulomb repulsion between the excess charges upon ligand loss. Loss of an electron in competition with carbonyl ligand loss has been noted previously for transition metal carbonyl cluster di- and trianions [37].

Maps of the anionic clusters $\left[\mathrm{CoRu}_{3}(\mathrm{CO})_{13}\right]^{-}$and $\left[\mathrm{Ru}_{6} \mathrm{C}(\mathrm{CO})_{16}\right]^{2-}$ were obtained where the cone and collision voltages remained constant throughout both experiments, and only the gas pressure in the collision cell was varied. Gas pressure was increased in fixed increments resulting in an approximately exponential increase in pressure with scan number (Fig. 7).

The gas pressure was increased until the signal was lost in the noise. The mass spectra are presented in an exactly analogous fashion to EDESI mass spectra, with a logarithmic pressure scale replacing cone (or collision) voltage on the $y$-axis. Each peak again corresponds to an individual ion, and 


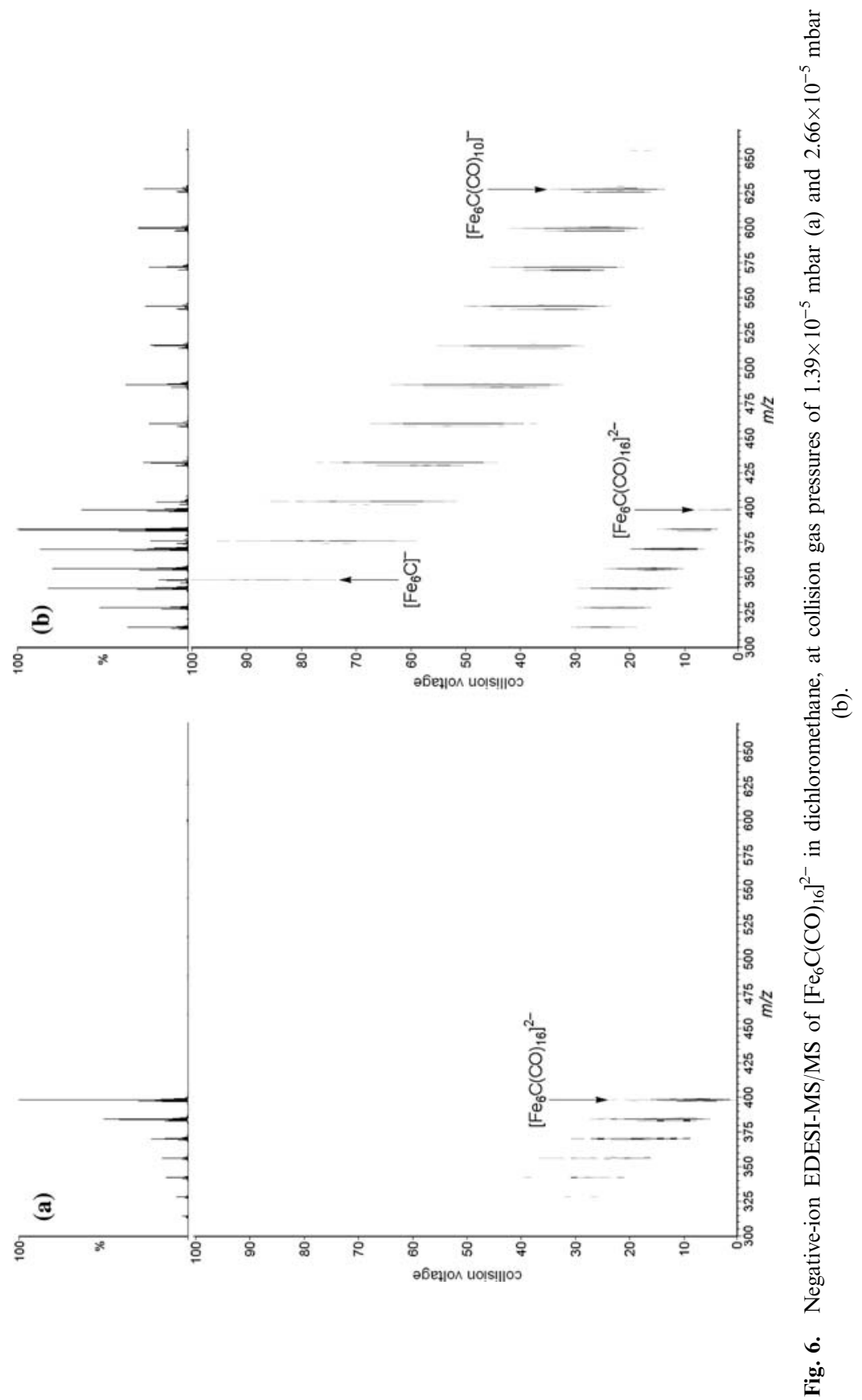




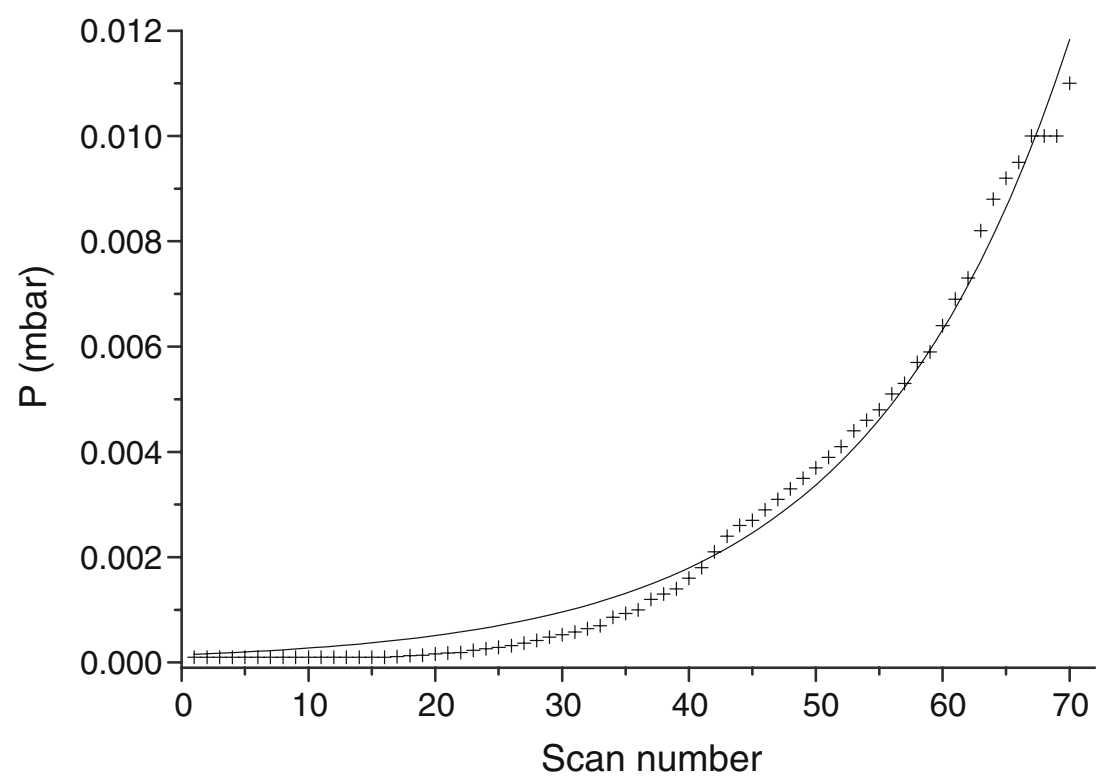

Fig. 7. Actual collision cell pressure by scan number for the MS/MS of $\left[\mathrm{Ru}_{6} \mathrm{C}(\mathrm{CO})_{16}\right]^{2-}$, with exponential fit line.

the mass spectra for these clusters (Figs. 8 and 9) qualitatively resemble the EDESI-MS of $\left[\mathrm{CoRu}_{3}(\mathrm{CO})_{13}\right]^{-}$and $\left[\mathrm{Ru}_{6} \mathrm{C}(\mathrm{CO})_{16}\right]^{2-}$.

A main difference between the maps generated by changing the collision gas pressure and those seen in EDESI-MS is in the ion current, which becomes gradually less as fewer ions emerge from the collision cell at higher gas pressures. Another feature is the simultaneous presence of many different fragment ions at a given gas pressure, e.g. at a pressure of ca. $7 \times 10^{-4} \mathrm{mbar}$, all of the ions $\left[\mathrm{CoRu}_{3}(\mathrm{CO})_{n}\right]^{-}(n=5-13)$ are present. In comparison, at the highest energy at which $\left[\mathrm{CoRu}_{3}(\mathrm{CO})_{13}\right]^{-}$is still visible in the EDESI-MS, the most fragmented species observed is $\left[\mathrm{CoRu}_{3}(\mathrm{CO})_{10}\right]^{-}$ [7]. As such, modifying the cone voltage represents a better discriminator for maximising the yield of a given ion compared to modification of the gas pressure. Setting the gas pressure at a high value has the advantage of increasing the absolute extent of fragmentation achievable at a given ion energy, but can significantly decrease the total ion current. Optimisation of collision gas pressure is clearly an important precursor to recording EDESIMS/MS data. 


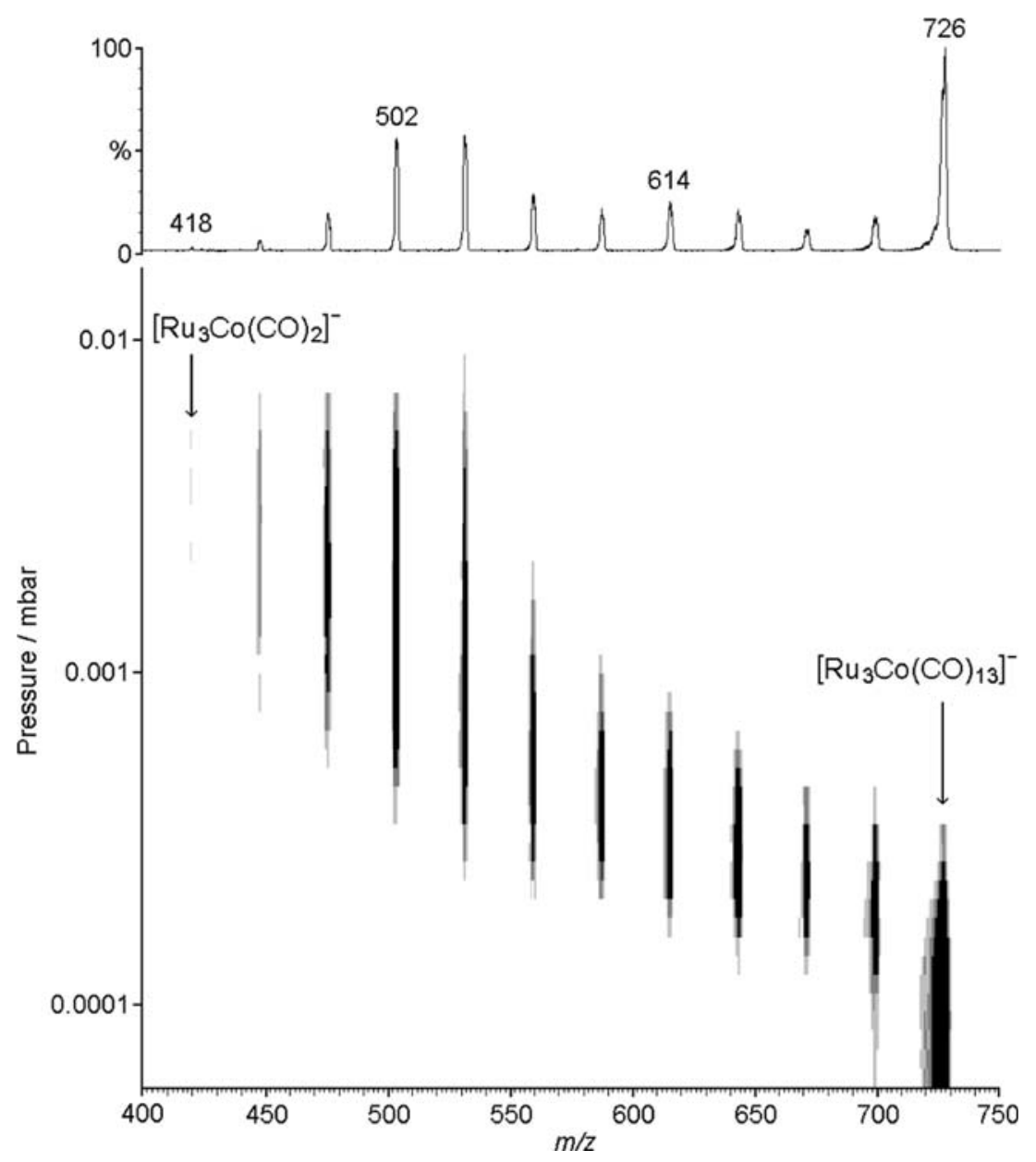

Fig. 8. Negative-ion $\mathrm{MS} / \mathrm{MS}$ of $\left[\mathrm{CoRu}_{3}(\mathrm{CO})_{13}\right]^{-}$, generated by varying the collision gas pressure from ca. 0.0001 to 0.01 mbar.

\section{ACKNOWLEDGMENTS}

We thank Prof. R. Roulet (EPFL) for donating the tetrairidium clusters. Colin Butcher is thanked for collecting some of the PDESI data. JSM thanks Natural Sciences and Engineering Research Council of Canada, the Canada Foundation for Innovation and the British Columbia Knowledge Development Fund for instrumentation and operational funding. SK thanks NSERC for a University Summer Research Fellowship. 


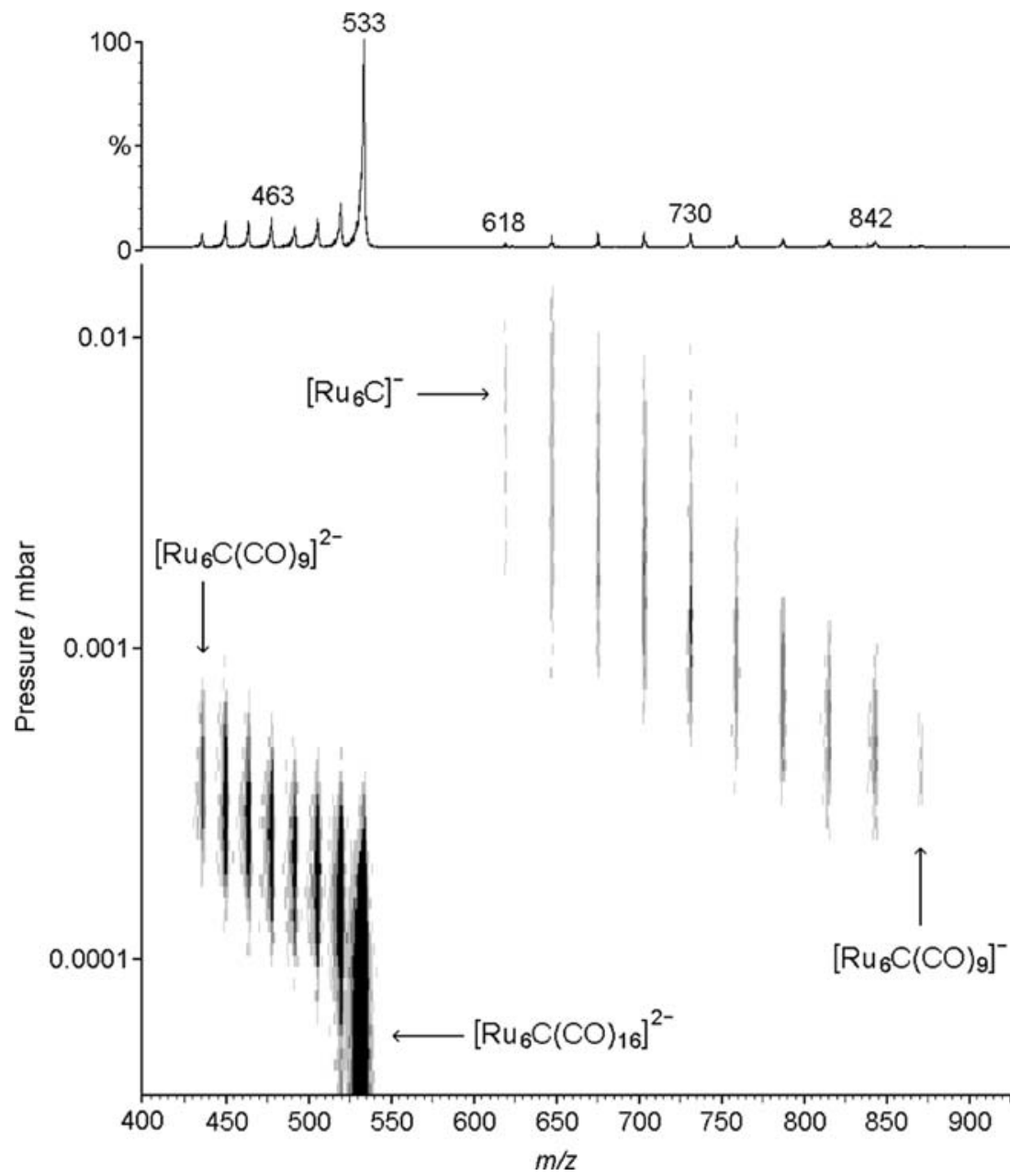

Fig. 9. Negative-ion $\mathrm{MS} / \mathrm{MS}$ of $\left[\mathrm{Ru}_{6} \mathrm{C}(\mathrm{CO})_{16}\right]^{2-}$, generated by varying the collision gas pressure from ca. 0.0001 to 0.01 mbar.

\section{REFERENCES}

1. C. R. Eady, B. F. G. Johnson, and J. Lewis (1975). J. Chem. Soc., Dalton Trans. 2606.

2. B. F. G. Johnson, R. D. Johnston, and J. Lewis (1968). J. Chem. Soc. (A) 2865.

3. (a) D. Braga, F. Grepioni, P. J. Dyson, B. F. G. Johnson, P. Frediani, M. Bianchi, and F. Piacenti (1992). J. Chem. Soc., Dalton Trans., 2565; (b) D. Braga, F. Grepioni, S. Righi, B. F. G. Johnson, P. J. Bailey, P. J. Dyson, J. Lewis, and M. Martinelli (1992). J. Chem. Soc., Dalton Trans., 2121; (c) P. J. Dyson, B. F. G. Johnson, J. Lewis, M. Martinelli, D. Braga, and F. Grepioni (1993). J. Am. Chem. Soc. 115, 9062. 
4. R. E. Winters and R. W. Kiser (1965). J. Phys. Chem. 69, 1618.

5. R. B. King (1966). J. Am. Chem. Soc. 88, 2075.

6. (a) B. F. G. Johnson, J. Lewis, I. G. Williams, and J. M. Wilson (1967). J. Chem. Soc. (A) 341; (b) B. F. G. Johnson, J. Lewis, I. G. Williams, and J. M. Wilson (1966). J. Chem. Soc., Chem. Commun. 391; (c) K. Edgar, B. F. G. Johnson, J. Lewis, I. G. Williams, and J. M. Wilson (1967). J. Chem. Soc. (A) 379; (d) B. F. G. Johnson and J. Lewis (1968). Acc. Chem. Res. 1, 245

7. W. Fellman, D. K. Huggins, H. D. Kaesz, and J. M. Smith (1964). J. Am. Chem. Soc. 86, 4841 .

8. B. F. G. Johnson, R. D. Johnston, J. Lewis, and B. H. Robinson (1966). J. Chem. Soc., Chem. Commun. 851.

9. (a) T. Blumenthal, M. I. Bruce, O. B. Shawkataly, B. N. Green, and I. Lewis (1984). J. Organomet. Chem. 269, C10; (b) S. Naylor and M. D. Vargas (1990). J. Organomet. Chem. 386, 275.

10. (a) C. J. McNeal, J. M. Hughes, G. J. Lewis, and L. F. Dahl (1991). J. Am. Chem. Soc.,113, 372; (b) J. P. Fackler Jr., C. J. McNeal, and R. E. P. Winpenny (1989). J. Am. Chem. Soc.,111, 6434.

11. (a) F. Hillenkamp, M. Karas, R. C. Beavis, and B. T. Chait (1991). Anal. Chem. 63, 1193; (b) D. C. Muddiman, R. Bakhtiar, S. A. Hofstadler, and R. D. Smith (1997). J. Chem. Educ. 74, 1288.

12. (a) S. A. Hofstadler, R. Bakhtiar, and R. D. Smith, (1996). J. Chem. Educ. 73, A82; (b) J. B. Fenn, M. Mann, C. K. Meng, S. F. Wong, and C. M. Whitehouse (1990). Mass Spec. Rev. 9, 37; (c) J. B. Fenn, M. Mann, C. K. Meng, S. F. Wong, and C. M. Whitehouse (1989). Science 246, 64.

13. (a) B. F. G. Johnson and J. S. McIndoe (2000). Coord. Chem. Rev. 200-202, 901; (b) W. Henderson and J. S. McIndoe, Mass Spectrometry of Inorganic and Organometallic Compounds (John Wiley \& Sons, Chichester, 2005).

14. (a) Y.-Y. Choi and W.-T. Wong (1999). J. Chem. Soc., Dalton Trans. 331; (b) W. Henderson, L. J. McCaffrey, and B. K. Nicholson (1998). Polyhedron, 17, 4291; (c) D. J. F. Bryce, P. J. Dyson, B. K. Nicholson, and D. G. Parker (1998). Polyhedron, 17, 2899; (e) M. Ferrer, R. Reina, O. Rossell, M. Seco, and G. Segales (1996). J. Organomet. Chem. 515, 205; (f) W. Henderson and B. K. Nicholson (1995). Chem. Commun. 2531; (g) R. Colton, A. D'Agostino, and J. C. Traeger (1995). Mass Spec. Rev. 14, 79.

15. (a) M. J. Dale, P. J. Dyson, B. F. G. Johnson, C. M. Martin, P. R. R. Langridge-Smith, and R. Zenobi (1996). J. Chem. Soc., Dalton Trans. 771; (b) G. Critchley, P. J. Dyson, B. F. G. Johnson, J. S. McIndoe, R. K. O'Reilly, and P. R. R. Langridge-Smith (1999). Organometallics 18, 4090; (c) P. J. Dyson, A. K. Hearley, B. F. G. Johnson, J. S. McIndoe, and P. R. R. Langridge-Smith (1999). Inorg. Chem. Commun. 2, 591; (d) W. J. Dollard, P. J. Dyson, T. Jackson, B. F. G. Johnson, J. S. McIndoe, and P. R. R. Langridge-Smith (1999). Inorg. Chem. Commun. 2, 587; (e) P. J. Dyson, J. E. McGrady, M. Reinhold, B. F. G. Johnson, J. S. McIndoe, and P. R. R. Langridge-Smith (2000). J. Clust. Sci. 11, 391; (f) P. J. Dyson, A. K. Hearley, B. F. G. Johnson, J. S. McIndoe, and P. R. R. Langridge-Smith (2000). J. Chem. Soc., Dalton Trans., 2521; (g) P. J. Dyson, A. K. Hearley, B. F. G. Johnson, P. R. R. Langridge-Smith, and J. S. McIndoe (2004). Inorg. Chem. 43, 4962.

16. A. J. Amoroso, L. H. Gade, B. F. G. Johnson, J. Lewis, J. P. R. Raithby, and W. T. Wong (1991). Angew. Chem. Int. Ed. Engl. 30, 107.

17. P. J. Dyson, B. F. G. Johnson, J. S. McIndoe, and P. R. R. Langridge-Smith (2000). Inorg. Chem. 39, 2430.

18. (a) P. J. Dyson, B. F. G. Johnson, J. S. McIndoe, and P. R. R. Langridge-Smith (2000). Rapid Commun. Mass Spectrom. 14, 311; (b) P. J. Dyson, B. F. G. Johnson, J. S. McIndoe, 
P. R. R. Langridge-Smith, and C. Whyte (2001). Rapid Commun. Mass Spectrom. 15, 895; (c) C. P. G. Butcher, P. J. Dyson, B. F. G. Johnson, P. R. R. Langridge-Smith, J. S. McIndoe, and C. Whyte (2002). Rapid Commun. Mass Spectrom. 16, 1595; (d) S. L. G. Husheer, O. Forest, M. Henderson, and J. S. McIndoe (2005). Rapid Commun. Mass Spectrom. 19, 1352; (e) V. N. Nemykin and P. Basu (2005). Inorg. Chim. Acta 358, 2876.

19. B. F. G. Johnson, J. Lewis, K. Wong, and M. McPartlin (1980). J. Organomet. Chem. 185, C17.

20. K. Besancon, G. Laurenczy, T. Lumini, R. Roulet, and G. Gervasio (1993). Helv. Chim. Acta. 76, 2926.

21. E. W. Hill, J. S. Bradley, J. Cassidy, and K. H. Whitmire (1990). Inorg. Synth. $27,182$.

22. G. L. Geoffroy, J. R. Fox, E. Burkhardt, H. C. Foley, A. D. Harley, and R. Rosen (1982). Inorg. Synth. 21, 57.

23. C. T. Hayward and J. R. Shapley (1983). Inorg. Chem. 21, 3816.

24. P. J. Dyson, A. K. Hearley, B. F. G. Johnson, J. S. McIndoe, and P. R. R. Langridge-Smith (2001). J. Clust. Sci. 12, 273.

25. P. J. Dyson, A. K. Hearley, B. F. G. Johnson, J. S. McIndoe, and P. R. R. Langridge-Smith (2001). Organometallics 20, 3970.

26. (a) W. Henderson, J. S. McIndoe, B. K. Nicholson, and P. J. Dyson (1996). Chem. Commun. 1183; (b) W. Henderson, J. S. McIndoe, B. K. Nicholson, and P. J. Dyson (1998). J. Chem. Soc., Dalton Trans. 519.

27. P. J. Dyson, N. Feeder, B. F. G. Johnson, J. S. McIndoe, and P. R. R. Langridge-Smith (2000). J. Chem. Soc., Dalton Trans. 1813.

28. C. P. G. Butcher, P. J. Dyson, B. F. G. Johnson, T. Khimyak, and J. S. McIndoe (2003). Chem. Eur. J. 9, 944.

29. A. F. Hill, Organotransition Metal Chemistry (RSC, Cambridge, 2002), pp. 87.

30. (a) V. Albano, P. L. Bellon, and V. Scatturin (1967). Chem. Commun. 730; (b) R. Whyman (1970). J. Organomet. Chem. 24, C35; (c) G. Phillips, S. Hermans, J. R. Adams, and B. F. G. Johnson (2003). Inorg. Chim. Acta 352, 110; (d) B. F. G. Johnson, T. Khimyak, F. W. Wansel, G. Phillips, S. Hermans, and J. R. Adams (2004). J. Clust. Sci. 15, 315.

31. K. M. Ervin (2001). Chem. Rev. 101, 391.

32. S. A. McLuckey (1991). J. Am. Soc. Mass Spectrom. 3, 599.

33. P. J. Dyson and J. S. McIndoe (2003). Inorg. Chim. Acta. 354, 68.

34. A. K. Hearley, B. F. G. Johnson, J. S. McIndoe, and D. G. Tuck (2002). Inorg. Chim. Acta. 334, 105.

35. See for examples (a) M. J. Charles and G. D. Marbury (1991). Anal. Chem. 63, 713; (b) I. Haller, U. A. Mirza, and B. T. Chait (1996). J. Am. Soc. Mass Spectrom. 7, 677; (c) K. Whalen, J. S. Grossert, and R. K. Boyd (1995). Rapid Commun. Mass Spectrom. 9, 1366.

36. (a) X.-B. Wang and L.-S. Wang (1999). Phys. Rev. Lett. 83, 3402; (b) L.-S. Wang and X.-B. Wang (2000). J. Phys. Chem. A, 104, 1978.

37. C. P. G. Butcher, B. F. G. Johnson, J. S. McIndoe, X. Yang, X.-B. Wang, and L.-S. Wang (2002). J. Chem. Phys. 116, 6560. 